\title{
SIMULATION DECISION GAMES AND EFFECTIVENESS OF THEIR USE FOR HIGHER EDUCATION AMONG WORKING AND NON-WORKING STUDENTS - PRACTICAL VIEW
}

\author{
Agnieszka DUDZIAK ${ }^{1}$, Monika STOMA2* \\ ${ }^{1}$ University of Life Sciences in Lublin, Department of Power Engineering and Transportation, Subdepartment \\ of Logistics and Business Management; agnieszka.dudziak@up.lublin.pl; ORCID: 0000-0002-4884-5403 \\ ${ }^{2}$ University of Life Sciences in Lublin, Department of Power Engineering and Transportation, Subdepartment \\ of Logistics and Business Management; monika.stoma@up.lublin.pl; ORCID:0000-0003-0404-699X \\ * Correspondence author
}

Purpose: The aim of the article is to assess the role of business simulations in shaping entrepreneurial skills at a university, where simulation games are used as a tool to support the teaching process. Therefore, the article presents the effectiveness of their use in academic conditions in a practical context, based on scientific research.

Design/methodology/approach: For the purposes of this article a survey was conducted among students who participated in classes using simulation games.

Findings: The introduction of innovative teaching methods at universities seems necessary due to the changing economic needs, and thus the need to acquire new competences in the labour market by employees (university graduates or students working during the course of study). One of the most difficult problems results from the discrepancy between the goals of the educational system and the insufficient preparation of lecturers to work in the present conditions, and the low level of development of their skills.

Research limitations/implications: It is advisable to carry out further scientific research in the field of using of simulation games due to the fact that they are increasingly used as a tool to support the process of practical learning.

Practical implications: Not without significance for the learning process is also the emotional involvement of participants who acquire knowledge more easily if they are interested in the given issue and understand the benefits resulting from it.

Social implications: Nowadays, it is impossible to imagine didactic activities carried out only in a conventional way. Currently implemented didactic processes at universities are often supported by active and modern teaching methods which include, among other things, simulation games. Their main advantage is that they facilitate the transfer of knowledge in an interesting way, teach creative problem solving, arouse interest and allow to gain new experiences, including interpersonal ones.

Originality/value: Active learning tools such as collaborative learning and problem-based learning can partly replace the traditional lecture-based method that continues to dominate in higher education. Advocates of active learning show that these innovative teaching strategies are more effective in increasing student motivation, knowledge acquisition, and general academic achievement. 
Keywords: simulation games, gamification, higher education, competences.

Category of the paper: Research paper.

\section{Simulation games and their reflection in practice}

Numerous authors define concepts of entrepreneurial competences and simulation games in a different approach and classify them (Cebrián \& Junyent, 2015). Simulation is an unusual situation in which the played roles are connected with a certain situation according to its image in the real world. The purpose of the simulation is to show a certain process from the beginning to the end. Simulations can, therefore, be presented as a miniaturized image (representation) of reality or a process model, e.g. economic, social, political or behavioural. Interestingly, the current generation of young people is beginning to be referred to as $3 \mathrm{~F}$ (ang. fun, friends, feedback) (Wawer, 2013).

The term "competence" is often assigned two different meanings. The first is the scope of powers and eligibilities specified in the rules of the activity. The second one concerns the key competences of employees (from the point of view of development opportunities) as a result of the use of educational simulation games - this is the scope of knowledge, skills and attitudes of an employee necessary to perform a designated professional role. However, there are also some doubts about the method using simulation games as a tool, therefore the main dilemma is the use of the game itself as a training method. Games are often associated with entertainment, and in particular they are delivered for children. However, there are nowadays many types of games dedicated to adult audiences that meet certain conditions that can be used as "serious games" for didactic purposes, as well as in relation to the assessment of the competences of employees or candidates for work (Kalinowski, 2016).

Various terms of "simulation" appear in the literature. Terms such as simulations, social simulations and simulation games are used interchangeably. Definitional problems do not result from the novelty of the method, they are rather a consequence of different ways of imitating reality and different ways of using simulation in practice.

Examples from this area can be:

- simulations of the decision-making process in which employers and employee representatives must reach an agreement on important economic dilemmas,

- simulations of solving misunderstandings between people representing different cultures,

- simulations of strategy development aimed at winning political elections,

- simulations of the conflict resolution process between the teacher and students in typical school situations, 
- simulations of assemblies (e.g. parliament, commune councils), discussion, negotiation and decision-making procedures in the form of voting. In the simulation of assembly techniques, the most important criteria of assessment will be the ability to negotiate, knowledge of the topic, and effectiveness of the participant's activities,

- simulations of negotiations (e.g. on NATO extension or on the conditions for ending a conflict in a local community).

Computer programs based on the simulation of civilization, social, cultural and economic processes are a specific form of simulation from the education area. The program's properties can help the teacher individualize the teaching process (https://koss.ceo.org.pl/).

What is worth emphasizing, entrepreneurial competences are not only related to work or business (e.g. planning, problem-solving, communication), but also concern everyday life, place and role of an individual in their environment (Czyżewska, Pitura, \& Szczepaniak, 2018).

\section{Materials and methods}

The object of the research was the way students perceive classes using simulation games. The main assumption was to indicate factors determining the selection of a particular type of games in terms of attractiveness and other benefits for working students and for those who do not work. The research was carried out on the basis of questionnaires completed by the students after the end of classes with the use of decision games.

The applied research method allowed to obtain a proper data set and analyse it in a simple way. Students represented different gender, mode and level of study, and fields of study; some of them declared that they were working, some were not taking up employment. Due to such a diverse group of respondents, it was possible to determine the differences in the approach to the topic under study, depending on the attitude of the respondents towards a rather unusual and still rare form of activities that are simulation games.

The various skills and competences in the modern market are a category that changes and depends on many factors. One of the most reliable methods of obtaining information on the changing needs of consumers on the market is questionnaire surveys. The research used in this work was carried out in 2019 among a group of 178 respondents - university students. The proprietary questionnaire was used, using a nonprobability sampling, as the research concerned only the students who took part in classes where decision games were implemented. The results were elaborated considering the division of respondents into various groups: on the basis of sex, mode and type of studies and, most importantly, employment. The questionnaire contained 15 questions of a closed nature. The results obtained after the conducted questionnaire research were developed statistically. 
As already mentioned, the main goal of the study was to identify factors that influence the students' opinions on the innovative method of classes conducted with the use of simulation games. Three supplementary goals were set to achieve the main goal:

1. Identification of the type of games that can be a variety of didactic classes at a university;

2. Identification of students who take up employment and linking this fact with the impact of games on potential professional competences.

3. Identification of factors that influence the assessment of simulation games in the context of benefits and additional competences for their participants.

In addition, the following research questions were formulated to carry out the study:

1. Do students, due to different sex (women and men), have the same preferences regarding the benefits of simulation games?

2. Do students, due to different employment status (working people and unemployed people), have the same observations about acquired competences?

To sum up, this paper presents the results of surveys on the influence of decision-making games on increasing the attractiveness and overall quality of teaching at the university and their impact on students who will be able to use their skills and competences in the labour market in the future.

\section{Results and discussions}

The introduction of innovative teaching methods at universities seems necessary due to the changing economic needs, and thus the need to acquire new competences in the labour market by employees (university graduates or students working during the course of study). One of the most difficult problems results from the discrepancy between the goals of the educational system and the insufficient preparation of lecturers to work in the present conditions, and the low level of development of their skills. Skills improvement processes using simulated games are the subject of numerous scientific studies (Fominykh, Uskova, Mantulenko, Kuzmina, \& Shuravina, 2016). Research results may be useful for teachers and students of higher education institutions in monitoring the quality of education, but also for constructing a program of activities in which games are used, with a view to ensuring the acquisition of specific desirable competences and skills. 
Active learning tools such as collaborative learning and problem-based learning can partly replace the traditional lecture-based method that continues to dominate in higher education. This topic often causes discrepancies among teachers. Nevertheless, advocates of active learning show that these innovative teaching strategies are more effective in increasing student motivation, knowledge acquisition, and general academic achievement. Motivation is necessary for learning but also for personal development. Therefore, it is important to find a stimulating environment that attracts the attention of students, as well as to implement teaching techniques to influence their motivation and learning skills without exposing academic discipline (Roig, \& Stoyanova, 2018). In addition to these positive ones, there are also critical opinions that question the contribution of student interaction to real learning. Not all teachers are their supporters, because not every class can be conducted using such a tool, and those that create such an opportunity require experience, preparation, skills in interpreting the obtained results and the "unconventional" approach of the person conducting the classes (Hernández-Lara, Perera-Lluna, \& Serradell-López, 2019).

Hence, in the studies carried out by the authors the participants were students who participated in activities supported by various simulation games. About $60 \%$ of the analysed research group was represented by men. Other variables, according to which the analysis was carried out, are given in Table 1.

Table 1.

Socio-demographic profile of the population surveyed

\begin{tabular}{|l|c|c|}
\hline \multicolumn{1}{|c|}{ Socio-demographic profile } & Number of respondents & Percentage share \\
\hline Total: & 178 & - \\
\hline Gender: & 107 & 60.1 \\
male & 71 & 39.9 \\
\hline female & 150 & \\
\hline Type of studies: & 28 & 84.3 \\
full-time studies & & 15.7 \\
part-time studies & 108 & 60.7 \\
\hline Mode of studies: & 70 & 39.3 \\
first-degree studies & & \\
second-degree studies & 93 & 52.2 \\
\hline Employment: & 85 & 47.8 \\
yes & & \\
no & 25 & 27.0 \\
\hline Industry: & 13 & 14.0 \\
trade & 43 & 46.0 \\
production & 12 & 13.0 \\
services & & \\
other & & \\
\hline
\end{tabular}

Source: the authors' own studies. 
Own research has shown different tendencies among working and non-working students. As mentioned above, the majority of respondents were men (60\%). The most represented group were full-time students - they constituted $84 \%$ of all respondents, including first-degree students $(60 \%)$. The share of working and non-working students was fairly similar, while the industries in which students were employed were not; and so the number of students working in particular industries was: in trade $-27 \%$, production $14 \%$, services - the highest share of $46 \%$, and $13 \%$ of students declared a different industry. The share of employment in particular industries by gender is presented in Figure 1.

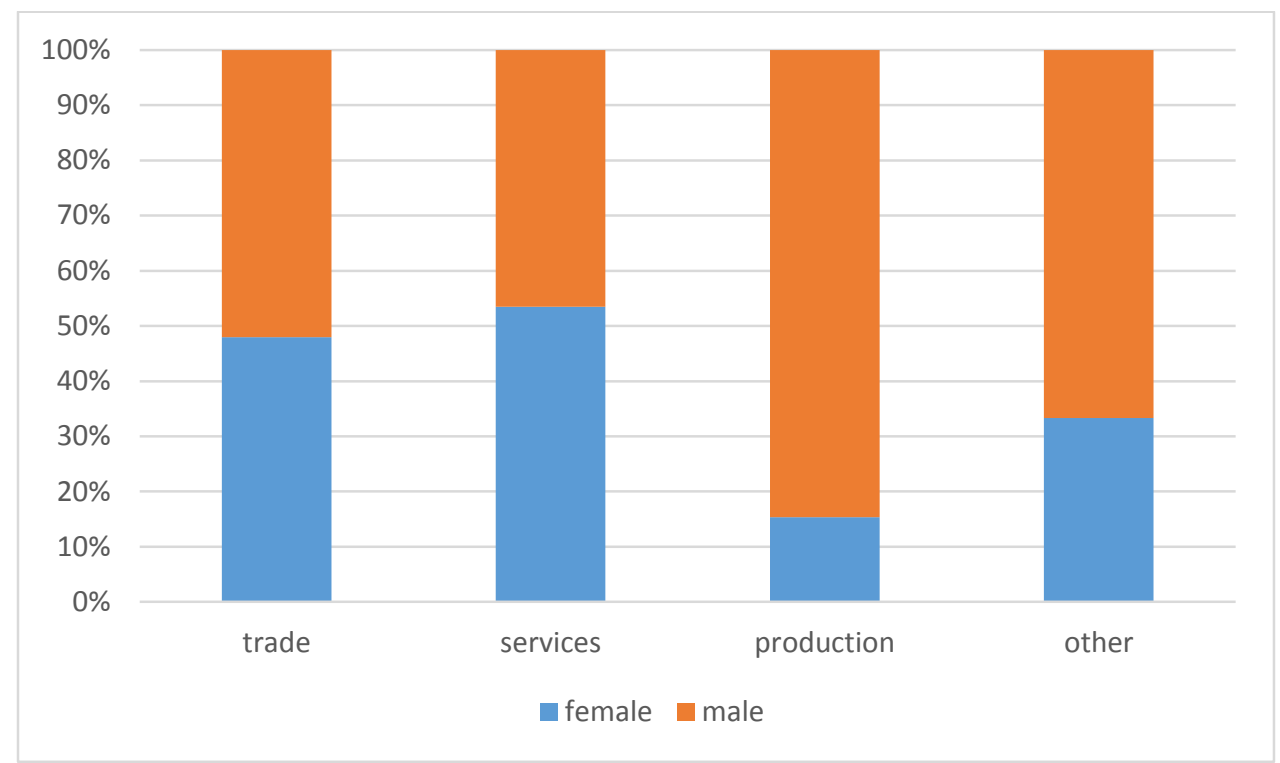

Figure 1. Share of employment of students in particular industries. Source: the authors' own studies.

The conducted research has shown that the assessment of competences that can be obtained during classes supported by simulation games among women is similar. Nevertheless, working women differ from women who do not work in the assessment as they decidedly better assessed the competence of managing the team, and rated their logical thinking skills, decision-making skills, ability to work in conditions of time pressure, ability to analyse and select information quite highly. A comparison of key factors is shown in Figure 2. 


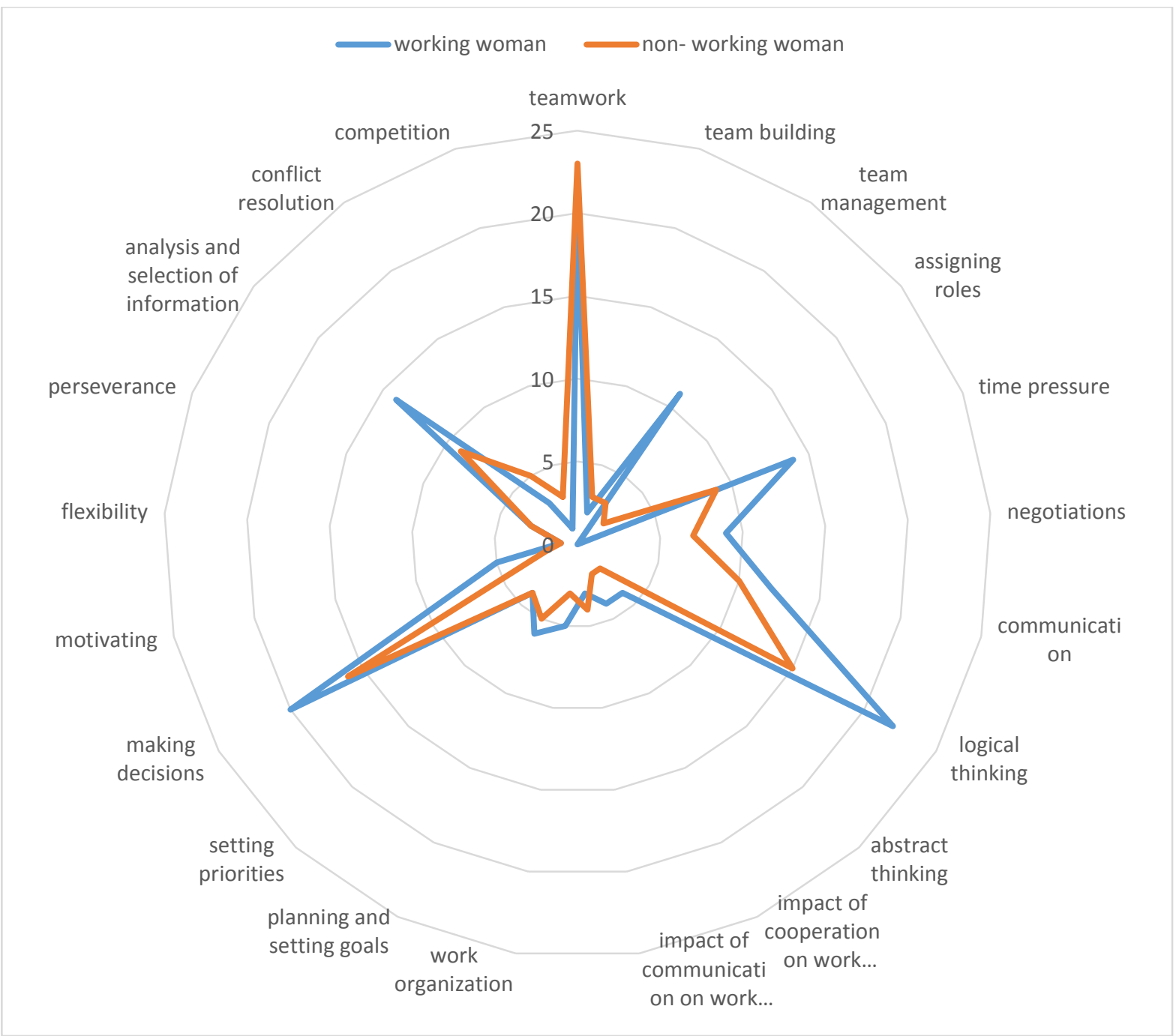

Figure 2. Competences that can be gained during classes supported by "simulation games" according to women's opinions. Source: the authors' own studies.

In the case of assessing the competences to be obtained, it can be clearly seen in the group of men that the trends in both groups are similar (working men and non-working men) Figure 3. 


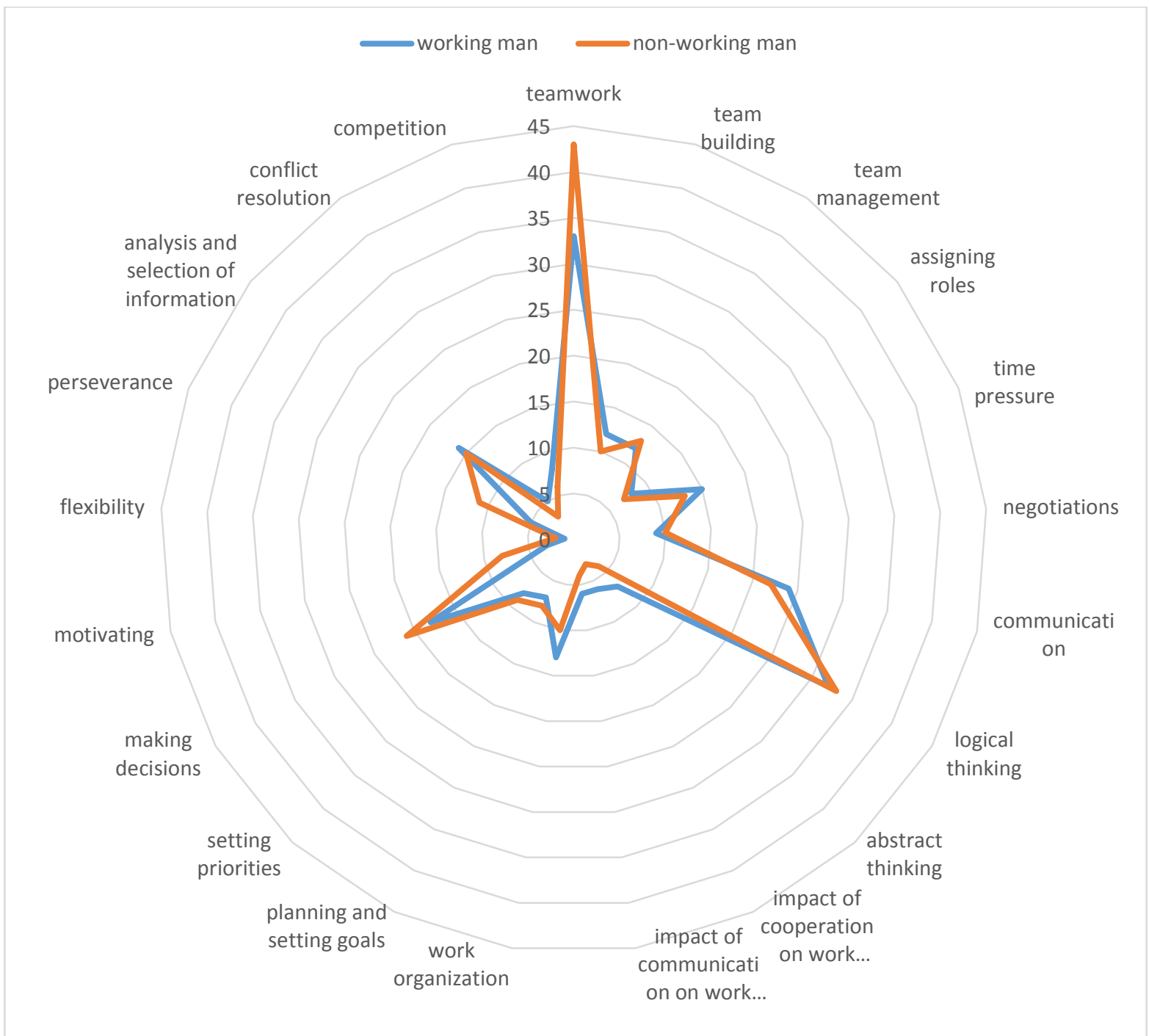

Figure 3. Competences that can be gained during activities supported by "simulation games" according to men's opinions. Source: the authors' own studies.

Students participating in the study also indicated the most attractive forms of simulation games. Interestingly, both groups have indicated "case study" as the most interesting form of a game. However, also board and computer games enjoyed quite high recognition, especially in the group of working women (Figure 4).

However, the main benefits that simulation games bring to students indicated by both working and non-working women are: making the curriculum more attractive, using theory in practice and learning through play. The biggest discrepancies between the two groups concerned the development of competences, because in the group of working women this benefit was noticed and indicated quite frequently (Figure 5).

In the case of men's competence assessment, the main benefits that simulation games bring to students according to both working and non-working men are: making the curriculum more attractive, group integration and creativity. The biggest discrepancies between the two groups concerned learning through play, because in the group of working men much attention was paid to this (Figure 5). 


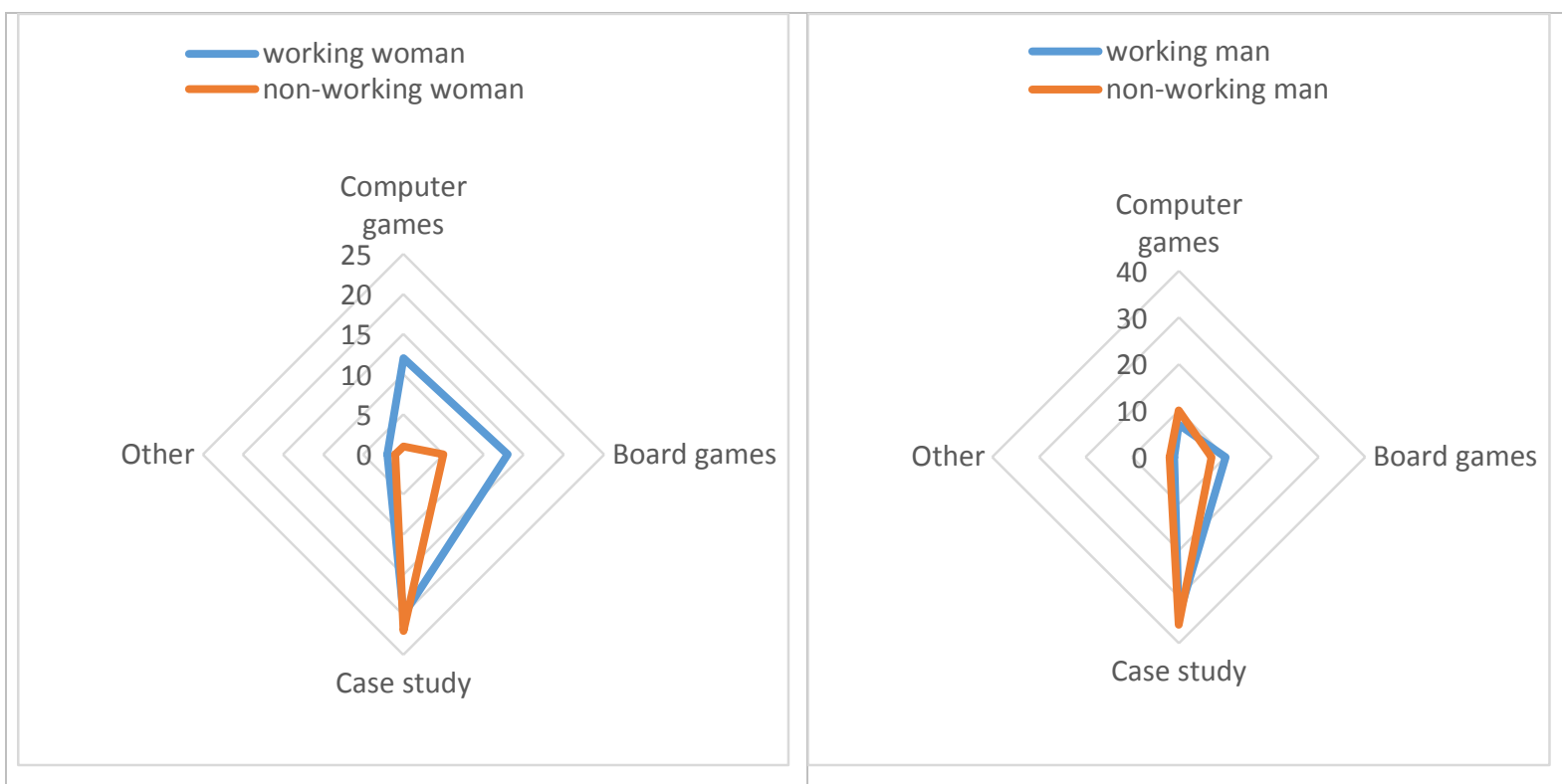

Figure 4. The most attractive types of "simulation games" in the opinion of students. Source: the authors' own studies.

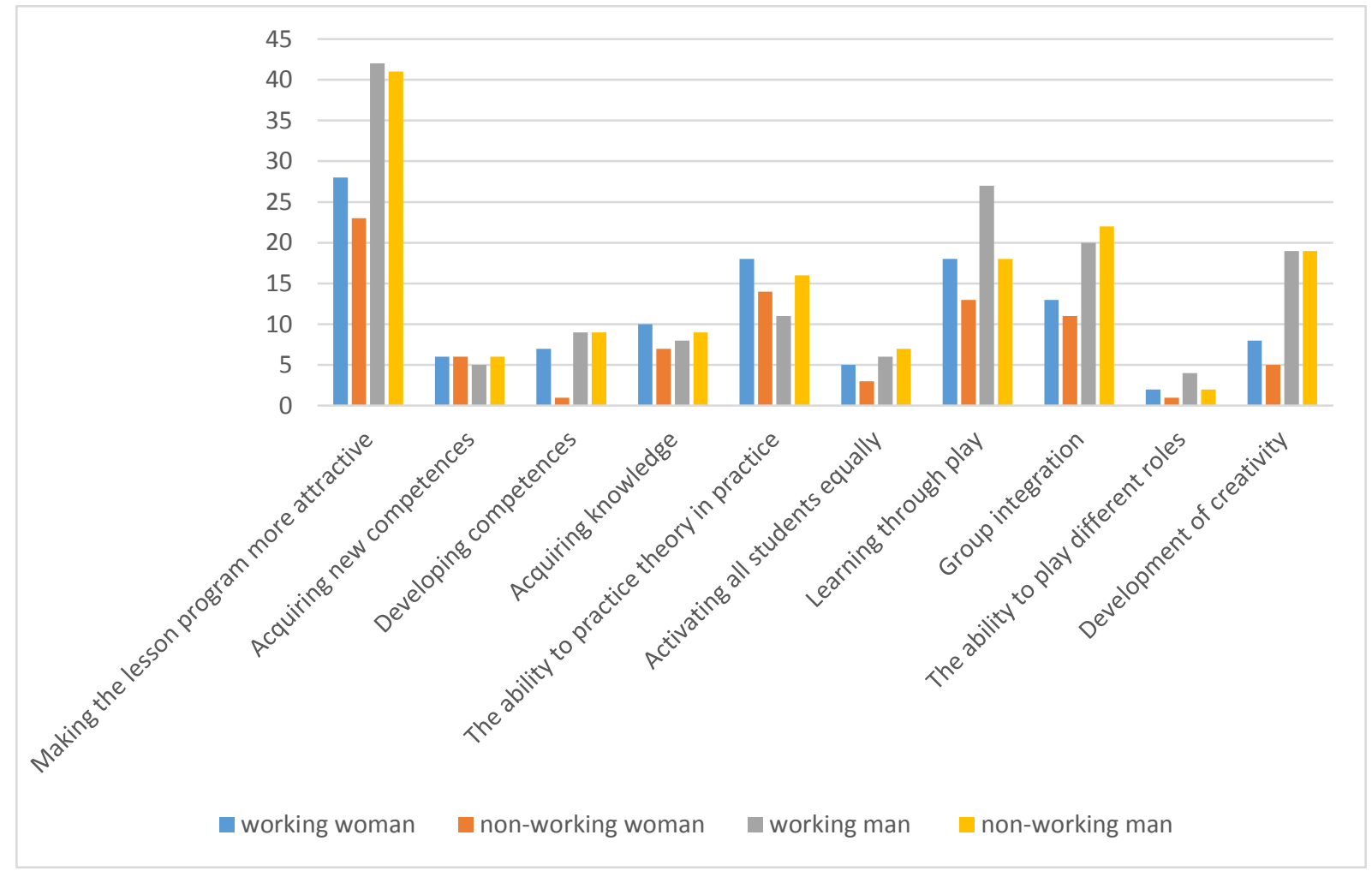

Figure 5. The benefits of classes including "simulation games" in the opinion of students. Source: the authors' own studies. 


\section{Conclusions}

Simulation decision games can and often are used as a tool to support the didactic process carried out in academic conditions. They represent the mapping of reality using dynamic models (Wawrzyńczyk-Kulik, 2013).

The conducted research made it possible to identify the most attractive simulation games used in university courses, especially with respect to the diversity of students due to their professional experience (working people pay attention to other practical aspects). In this case, this situation may indicate the need to change the existing models of conducting classes to those more flexible, adapted to the requirements of the labour market and specifically required competences. The obtained research results can be valuable information for teachers and practitioners who are interested in the implementation of practical classes, but also those who would like to enrich the classes, thus increasing the practical value. This is an important issue in the area of shaping the strategy of activities regarding further directions of development of the teaching process, with particular emphasis on student preferences and their expectations.

The conducted research allowed to identify key factors influencing the assessment of didactic classes supported by innovative practical tools in the form of simulation games. The main conclusions of the study seem to be as follows:

- simulation games are very popular among students,

- working students evaluate games from a different point of view than non-working students,

- the types of games that are more popular are the so-called case study and board games,

- among the most important benefits mentioned by students are: the program's attraction, learning through play, group integration and creativity as well as using theory in practice,

- the main competences pointed out by women are: teamwork, logical thinking, dealing with time pressure, decision-making, analysis and selection of information; while what distinguishes working from non-working women is the competence of managing teams,

- the main competences pointed out by men are: teamwork, logical thinking, decisionmaking and persistence; there were no major discrepancies between working and nonworking men.

The study, due to the selection of the target sample, cannot be generalized to the entire population. Implications that go beyond our study group are only representative due to the selected group of respondents who participate in didactic activities supported by simulation games, because it cannot be a representative sample for the entire population. 


\section{References}

1. Cebrián, G., \& Junyent, M. (2015). Competencies in education for sustainable development: Exploring the student teachers' views. Sustainability, 7(3), 2768-2786. doi: doi.org/ $10.3390 / \mathrm{su} 7032768$.

2. Czyżewska, M., Pitura, W., \& Szczepaniak, E. (2018). Gry symulacyjne jako metoda rozwijania kompetencji przedsiębiorczych w szkołach średnich na przykładzie branżowych symulacji biznesowych. Przedsiębiorczość-Edukacja, 14, 483-494.

3. Fominykh, M.V., Uskova, B.A., Mantulenko, V.V., Kuzmina, O.N., \& Shuravina, E.N. (2016). A model for the education of a student of a vocational pedagogical educational institution through the gaming simulation. International Electronic Journal of Mathematics Education, 11(8), 2814-2840.

4. Hernández-Lara, A.B., Perera-Lluna, A., \& Serradell-López, E. (2019). Applying learning analytics to students' interaction in business simulation games. The usefulness of learning analytics to know what students really learn. Computers in Human Behavior, 92, 600-612. doi: 10.1016/j.chb.2018.03.001

5. Kalinowski, M. (2016). Dylematy projektowania i stosowania symulacyjnych gier decyzyjnych w rozwoju pracowników. Journal of Management and Finance, 14(1).

6. Roig, G.A., \& Stoyanova, A. (2018). Applying Active Learning Methods in Higher Education. Revista d'Innovació i Recerca en Educació, 11(2), 65.

7. Wawer, M. (2013). Edukacyjne gry symulacyjne w rozwoju kompetencji pracowników. Edukacja-Technika-Informatyka, 4(2), 220-225.

8. Wawrzyńczyk-Kulik, M. (2013). Simulation game as a tool supporting the teaching process within the "Basics of entrepreneurship" subject". Zeszyty Naukowe WSEI seria: Ekonomia, 6(1), 303-321.

9. https://koss.ceo.org.pl/. 